\title{
Proapoptotic Bcl-2 family member Bim is involved in the control of mast cell survival and is induced together with $\mathrm{Bcl}-\mathrm{X}_{\mathrm{L}}$ upon IgE-receptor activation
}

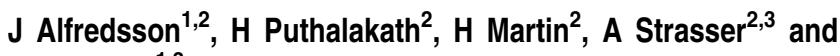 \\ G Nilsson ${ }^{\star, 1,3}$ \\ 1 Department of Genetics and Pathology, Rudbeck Laboratory, Uppsala \\ University, Uppsala, Sweden \\ 2 The Walter and Eliza Hall Institute of Medical Research, Melbourne, Australia \\ 3 These authors contributed equally to this work \\ * Corresponding author: G Nilsson, Research Group on Mast Cell Biology, \\ Department of Genetics and Pathology, Rudbeck Laboratory, Uppsala \\ University, SE-751 85 Uppsala, Sweden. Tel: + 4618 6113876; \\ fax: + 4618 558931; E-mail: Gunnar.Nilsson@genpat.uu.se
}

Received 22.3.04; revised 01.10.04; accepted 12.10.04; published online 10.12.04 Edited by DR Green

\begin{abstract} members.

Cell Death and Differentiation (2005) 12, 136-144.

doi:10.1038/sj.cdd.4401537

Published online 10 December 2004
\end{abstract}

Mast cells play critical roles in the regulation of acute and chronic inflammations. Apoptosis is one of the mechanisms that limit and resolve inflammatory responses. Mast cell survival can be controlled by growth factors and activation of the IgE-receptor Fc\&RI. Members of the Bcl-2 protein family are critical regulators of apoptosis and our study provides evidence that the proapoptotic BH3-only family member Bim is essential for growth factor deprivation-induced mast cell apoptosis and that Bim levels increase upon Fc\&Rl activation. Bim deficiency or Bcl-2 overexpression delayed or even prevented cytokine withdrawal-induced mast cell apoptosis in culture. The prosurvival protein $\mathrm{Bcl}-\mathrm{X}_{\mathrm{L}}$ and the proapoptotic Bim were both induced upon $\mathrm{Fc} \varepsilon \mathrm{RI}$ activation. These results suggest that Bim and possibly also other BH3-only proteins control growth factor withdrawal-induced mast cell apoptosis and that the fate of mast cells upon FceRl activation depends on the relative levels of pro- and antiapoptotic Bcl-2 family

Keywords: apoptosis; Bim; Bcl- $\mathrm{X}_{\mathrm{L}}$; $\mathrm{Bcl}-2$; mast cell; stem cell factor; interleukin-3

Abbreviations: $\mathrm{BH}, \mathrm{Bcl}-2$ homology; $\mathrm{BMMC}$, bone marrowderived mast cell; SCF, stem cell factor

\section{Introduction}

Mast cells are important effector and regulatory cells in inflammatory reactions. Upon activation, mast cells release and secrete inflammatory mediators, such as histamine, proteases, prostaglandin, leukotrienes and cytokines (e.g. TNF- $\alpha$ ). Mast cells originate from hemopoietic stem cells in the bone marrow and are dispersed throughout most tissues. Although mast cells have been studied mostly in the context of allergic diseases, it is now evident that these cells also play a critical role in host defense against certain pathogens. ${ }^{1}$ Moreover, it has been demonstrated that mast cells can influence the onset and/or disease severity of chronic inflammatory reactions, for example in certain autoimmune diseases. $^{2}$

In healthy individuals, the numbers of tissue mast cells are kept at a constant level, but during inflammation, such as allergy, ${ }^{3}$ allergic asthma ${ }^{4}$ or rheumatoid arthritis, ${ }^{5}$ their numbers are increased. When the inflammation has resolved, mast cell numbers decline, and there is evidence that apoptotic cell death is involved in this process. The regulation of mast cell homeostasis has not been studied in any great detail and the molecular mechanisms involved in mast cell apoptosis still need to be deciphered.

Mammals have two distinct apoptosis signaling pathways ${ }^{6}$ that converge upon activation of aspartate-specific cysteine proteases (caspases) which demolish cells by cleaving vital structural proteins and by activating latent enzymes that degrade DNA. ${ }^{7}$ The Bcl-2 family of prosurvival and proapoptotic proteins are critical regulators of cell survival ${ }^{7}$ and the balance between the two subgroups determines whether a cell will survive or undergo apoptosis. The prosurvival Bcl-2 family members include $\mathrm{Bcl}-2$, $\mathrm{Bcl}-\mathrm{X}_{\mathrm{L}}, \mathrm{Bcl}-\mathrm{w}, \mathrm{A} 1, \mathrm{Mcl}-1$ and Boo/Diva and these proteins all share three or four regions of homology, called $\mathrm{Bcl}-2$ homology $(\mathrm{BH})$ regions. The proapoptotic family members can be further divided into two subgroups, the Bax/Bak-like proteins and the BH3-only proteins. The Bax/Bak subgroup consists of Bax, Bak, Bok/Mtd, Bcl- $x_{S}, B c l-G_{L}$ and Bfk and these proteins share two or three $\mathrm{BH}$ regions and, surprisingly, at least in the case of Bax also extensive structural similarity with their prosurvival relatives. ${ }^{7}$ The $\mathrm{BH}$-only proteins include Bik/Blk/Nbk, Bad, Hrk/DP5, Bid, Bim/Bod, Noxa, Bmf and Puma/Bbc3 and they share with each other and the $\mathrm{Bcl}-2$ family only the $\mathrm{BH} 3$ region. ${ }^{8}$ The $\mathrm{BH} 3$ domain is essential for the binding of these proapoptotic proteins to the antiapoptotic Bcl-2 family members and for inducing apoptosis. ${ }^{8}$ Genetic and biochemical experiments have indicated that the $\mathrm{BH} 3$-only proteins initiate programmed cell death and stress-induced apoptosis and that the Bax/Baklike proteins play an essential role in cell killing further downstream. 9,10 $^{9}$

Knowledge about the role of $\mathrm{Bcl}-2$ family members in the regulation of mast cell survival and apoptosis is limited. It has been shown that $\mathrm{Bcl}-2$ and $\mathrm{Bcl}-\mathrm{X}_{\mathrm{L}}$ are expressed in mast cells, ${ }^{11-13}$ but very little is known about their function in these cells. It has been reported that bax-/- and bcl-2-/- mice have abnormal numbers of mast cells in certain tissues but no general difference with wt animals were observed. ${ }^{14}$ We have previously shown that the Bcl-2 family member A1 is critical for 
the prosurvival stimuli triggered by crosslinking of the highaffinity $\lg$ E receptor, $\mathrm{Fc}_{\mathrm{c}} \mathrm{RI}{ }^{15}$

In this study, we provide the first evidence for an essential function of the proapoptotic $\mathrm{BH} 3-$ only protein Bim in mast cells and that its expression can be regulated by $\mathrm{Fc} \varepsilon \mathrm{RI}$ activation.

\section{Results}

\section{Bim is an inducer of cytokine withdrawal-induced apoptosis in mast cells}

To examine whether Bim has a function in the regulation of growth factor withdrawal-induced mast cell apoptosis, we compared the survival of in vitro-developed bone marrowderived mast cells (BMMC) from bim $-/{ }^{16}$ and wt mice. In order to further study the role of Bcl-2 family members in the regulation of mast cell survival and apoptosis, mast cells were also generated from vav- $b c l-2$ transgenic mice, which overexpress $\mathrm{Bcl}-2$ in all hemopoietic cells, including mast cells. ${ }^{17}$ The mast cells were produced in either IL-3, or in the presence of both IL-3 and stem cell factor (SCF). The BMMC developed from the wt, bim-/- and vav-bcl-2 transgenic mice all had typical mast cell morphology and staining of granula by toluidine blue. Flow cytometric analysis demonstrated that the different genotypes expressed the SCF-receptor Kit and the IgE-receptor $\mathrm{F}_{\mathrm{C} \varepsilon \mathrm{RI}}$ to similar extent (Figure 1).

It has previously been demonstrated that mast cells undergo apoptosis as a result of growth factor withdrawal. ${ }^{18,19}$ In our experiments, the wt, bim-/- and vav-bcl-2 transgenic mast cells were deprived of either IL-3, IL-3 and SCF, or of SCF alone. Cell death was determined by staining with propidium iodide followed by flow cytometric analysis. After
$48 \mathrm{~h}$ of IL-3 deprivation from mast cells produced in IL-3 alone, only $13 \%$ wt cells had survived, whereas $42 \%$ of the bim-1cells were still alive (Figure 2). After $15 \mathrm{~h}$ of growth factor (IL-3 plus SCF) deprivation of mast cells produced in both IL-3 and SCF, only $8 \%$ of the wt cells remained alive, whereas $50 \%$ of the bim-/- cells were still alive (Figure 3 ). When only SCF was withdrawn from BMMC produced in IL-3 plus SCF, $29 \%$ of the wt BMMC remained alive after $48 \mathrm{~h}$, while $57 \%$ of the bim-1- mast cells had survived (Figure 4). Higher concentrations of IL-3 delayed the cell death, but did not rescue the cells

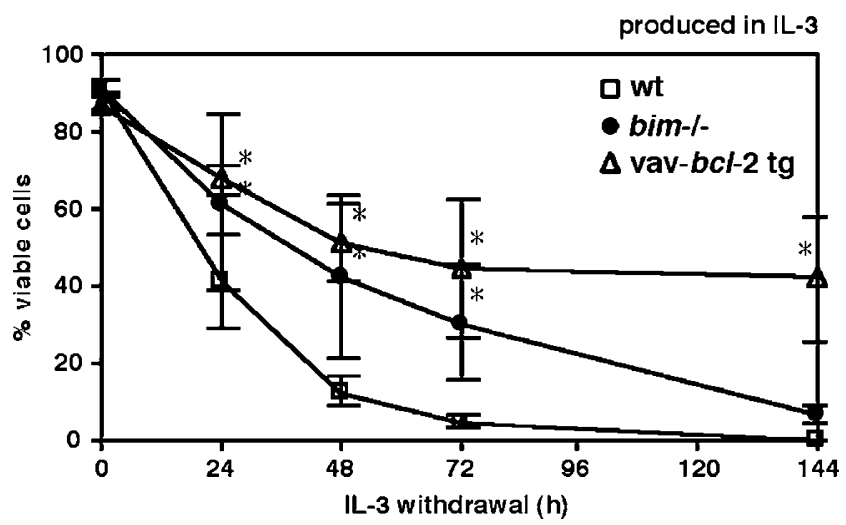

Figure 2 Bim deficiency and $b c /-2$ transgene expression inhibit IL-3 withdrawal-induced mast cell death. Wt, bim-l- and vav-bcl-2 transgenic BMMC produced in IL-3 were deprived of IL-3, and cell viability was analyzed at the time points indicated. Cell viability was determined by propidium iodide staining and flow cytometric analysis. Data are presented as the mean \pm S.D. $(n=4)$. Significant differences compared to wt were obtained as indicated $\left({ }^{\star} P<0.05\right)$

\section{Kit expression}

\section{FceRl expression}
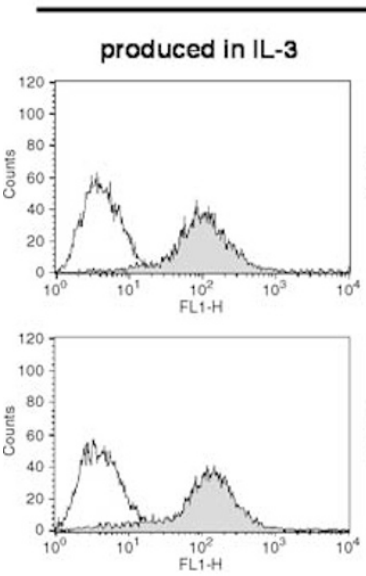

produced in IL-3 and SCF
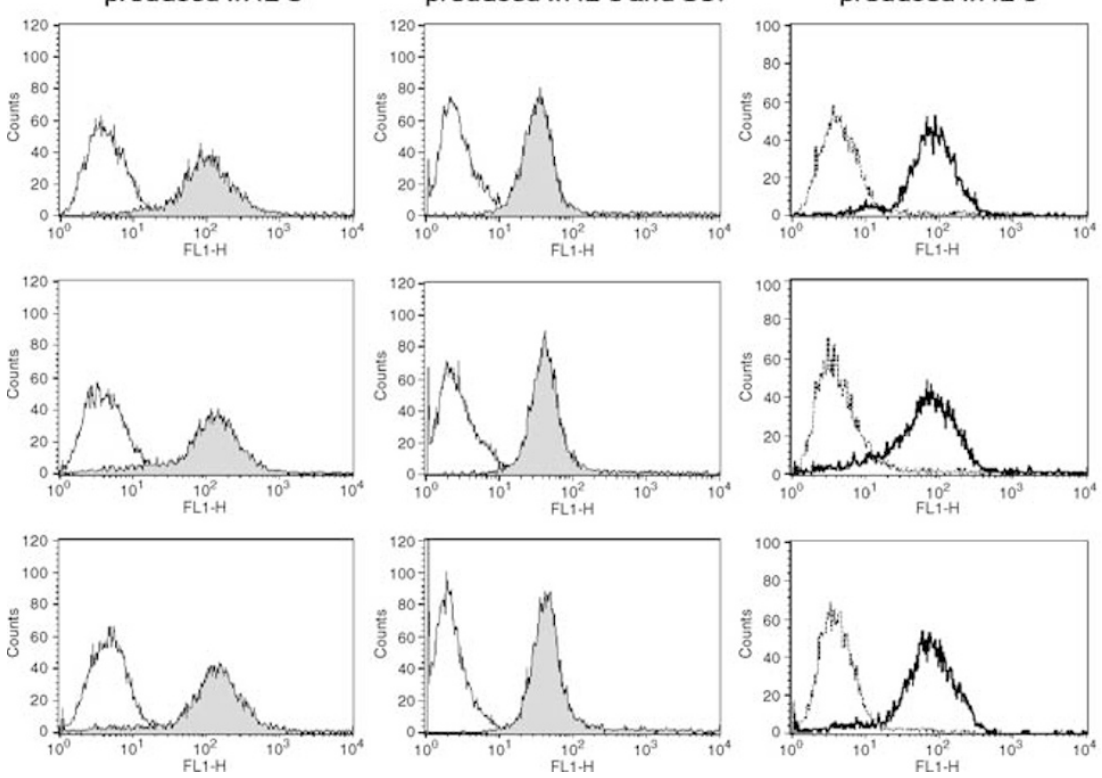

produced in IL-3 and SCF

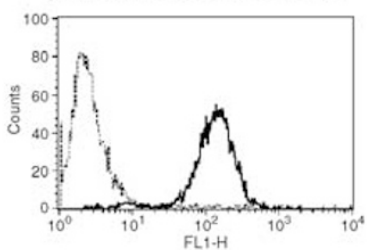

wt

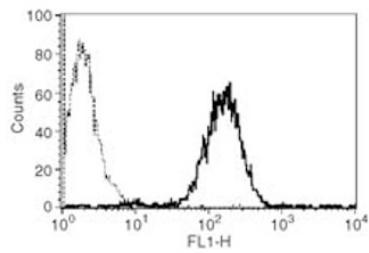

bim-/-

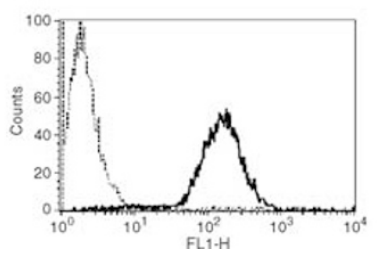

vav-bcl-2 tg

Figure $1 \mathrm{Wt}$, bim-/- and vav-bcl-2 transgenic BMMC express the receptors Kit and Fc\&RI to similar extent. By flow cytometric analysis, the receptor expression was analyzed on BMMC produced in IL-3 and on BMMC produced in a combination of IL-3 plus SCF. Left panel: filled peaks = Kit expression, empty peaks = isotype control. Right panel: thick line $=\mathrm{F} c \varepsilon R \mathrm{R}$ expression, dotted line $=$ isotype control. The results shown are representative of three independent experiments 


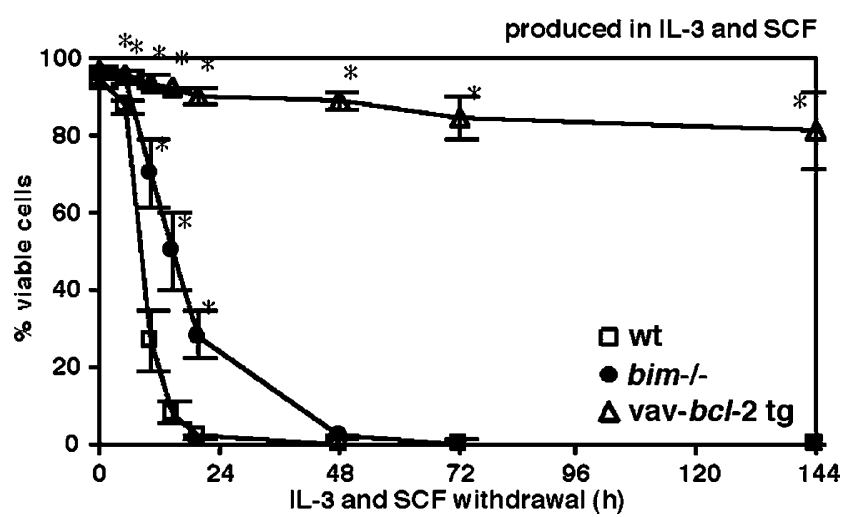

Figure 3 Bim deficiency and $b c /-2$ transgene expression inhibit mast cell death induced by removal of IL-3 and SCF. Wt, bim-I- and vav-bcl-2 transgenic BMMC produced in IL-3 and SCF were deprived of both IL-3 and SCF, and cell viability was analyzed at the time points indicated as described in Figure 2. Data are presented as the mean \pm S.D. $(n=6)$. Significant differences compared to wt were obtained as indicated $\left({ }^{*} P<0.05\right)$

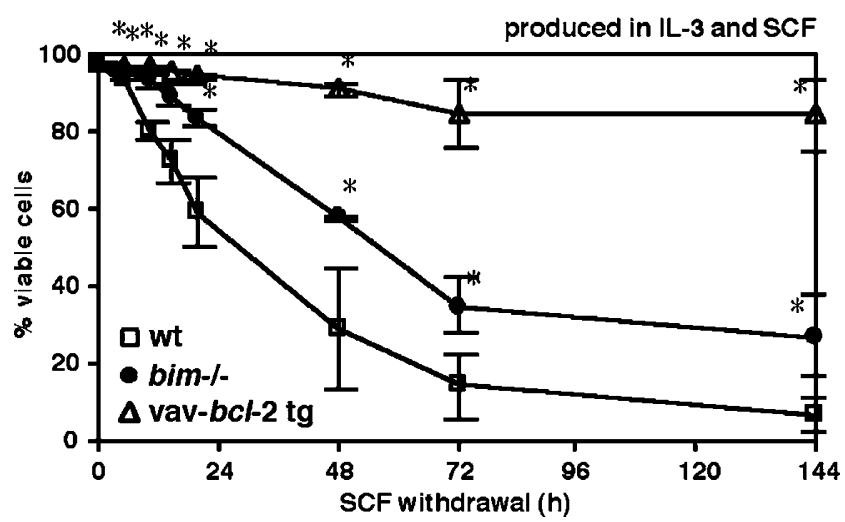

Figure 4 Bim deficiency and $b c l-2$ transgene expression inhibit SCF withdrawal-induced mast cell death. Wt, $b i m-l-$ and vav-bcl-2 transgenic BMMC produced in IL-3 and SCF were deprived of SCF, and cell viability was analyzed at the time points indicated as described in Figure 2. Data are presented as the mean \pm S.D. $(n=4)$. Significant differences compared to wt were obtained as indicated $\left({ }^{*} P<0.05\right)$

from undergoing apoptosis (data not shown). The results demonstrate for the first time that Bim is involved in the induction of mast cell death following growth factor withdrawal. Our results also show that IL-3 alone is not sufficient to promote survival of mast cells produced in both IL-3 plus SCF.

We also investigated the effect of overexpressing the prosurvival gene $b c /-2$ on growth factor withdrawal-induced mast cell apoptosis. Overexpression of Bcl-2 protected mast cells even more potently against cytokine deprivation-induced apoptosis than did loss of Bim (Figures 2-4). Hence, additional $\mathrm{Bcl}-2$ inhibitable death inducers besides Bim, most likely other BH3-only proteins, may be involved in the mast cell death triggered by growth factor withdrawal.

When growth factors were withdrawn from the vav- $b c l-2$ transgenic BMMC that had been produced in both IL-3 and SCF, there was an almost complete rescue from cell death even after 6 days, the latest time point studied (Figures 3 and 4). When IL-3 was withdrawn from the BMMC produced in only IL-3, overexpression of $\mathrm{Bcl}-2$ also provided substantial protection from apoptosis, but not as much as for the cells produced in both IL-3 and SCF (Figure 2).

An interesting observation was that mast cells produced in both IL-3 and SCF are much more sensitive to growth factor withdrawal than BMMC produced in IL-3 alone (Figures 2 and 3 ). For wt mast cells produced in IL-3, it took 3 days of growth factor withdrawal before most cells were dead (Figure 2). However, when wt mast cells that had been produced in both IL-3 plus SCF were starved of their growth factors, almost all cells were already dead after $20 \mathrm{~h}$ (Figure 3 ). Together with the observation that upon cytokine withdrawal Bcl-2 overexpression can almost completely rescue BMMC produced in IL-3 and SCF but only partially rescue those grown in IL-3, these results indicate that there are significant differences in the mechanisms regulating apoptosis following growth factor withdrawal, depending on whether mast cells have been produced in IL-3 alone or by the combined stimulation with IL3 and SCF.

\section{The prosurvival effect of IgE-receptor activation is not due to inactivation of Bim}

We also investigated whether inhibition of Bim could be involved in activation-induced survival of mast cells. In order to examine this, wt, bim-/- and vav-bcl-2 transgenic BMMC were deprived of growth factors with or without prior IgEreceptor crosslinking. If inactivation of Bim was essential for the prosurvival stimuli induced by IgE-receptor crosslinking, one would expect no additional prosurvival effect in $\mathrm{Fc} \varepsilon \mathrm{RI}$ stimulated bim-1- mast cells compared to nonstimulated bim-/- cells. However, both the wt and the bim-/- mast cells obtained a clear prosurvival stimulus upon $\mathrm{Fc} \varepsilon \mathrm{RI}$ activation, indicating that inhibition of Bim alone cannot be the sole prosurvival activity of $\mathrm{Fc}_{\varepsilon} \mathrm{RI}$ stimulation (Figure $5 \mathrm{a}, \mathrm{b}, \mathrm{d}$ and e).

\section{FceRI stimulation does not promote survival in SCF-deprived or Bcl-2 overexpressing mast cells}

As already described above, the mechanisms of growth factor withdrawal-induced BMMC death depends on the cytokines in which they have been produced. Similarly, we found that the method of mast cell production affected $\mathrm{Fc} \varepsilon \mathrm{R}$ l activationinduced BMMC survival. When only SCF was withdrawn from BMMC produced in IL-3 plus SCF, no prosurvival effect was obtained as a result of IgE-receptor crosslinking (Figure $5 \mathrm{c}, \mathrm{f}$ and i). This differed from the experiments in which both growth factors (IL-3 plus SCF) were withdrawn from mast cells (Figure $5 \mathrm{~b}$ and e), and from the experiments in which IL-3 was withdrawn from mast cells produced in IL-3 alone (Figure 5a,d and $\mathrm{g}$ ). In addition, we found that vav- $b c l-2$ transgenic mast cells produced in IL-3 plus SCF did not survive better upon cytokine withdrawal when activated through their Fc\&R compared to cells not stimulated through the Fc\&RI (Figure $5 \mathrm{~h}$ and i).

\section{Bim and $B c l-X_{L}$ proteins are upregulated upon IgE-receptor crosslinking}

We next examined the expression of several pro- and antiapoptotic proteins of the Bcl-2 family in BMMC and in 

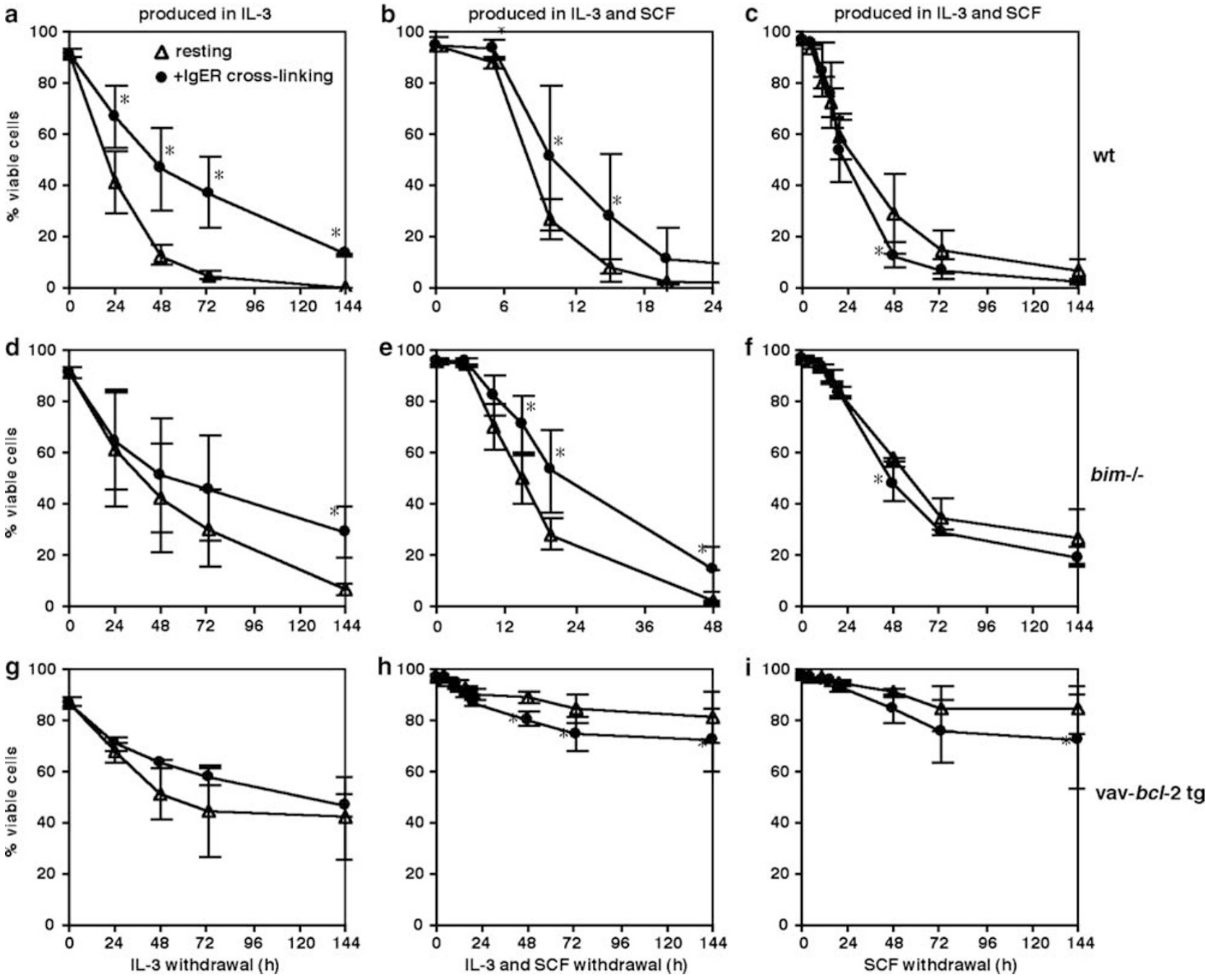

Figure 5 Absence of Bim does not affect the prosurvival stimulus from lgE-receptor crosslinking. In the experiments shown (a-i) wt, bim-l- or vav-bcl-2 transgenic BMMC were activated by crosslinking of the FceRI by lgE, followed by withdrawal of growth factors. (a, $\mathbf{d}$ and $\mathbf{g}$ ) BMMC produced in IL-3 were deprived of IL-3, with or without IgE-receptor activation prior to growth factor withdrawal. (b, e and $\mathbf{h}$ ) BMMC produced in IL-3 and SCF were activated and deprived of IL-3 and SCF. (c, $f$ and i) BMMC produced in IL-3 and SCF were activated, and SCF was withdrawn. In all experiments, cell viability was analyzed as described in Figure 2 . Data are presented as the mean \pm S.D. $(n=4-6)$. Significant effects compared to resting cells were obtained as indicated $\left({ }^{*} P<0.05\right)$

the C57 mast cell line (Figure 6). The C57 mast cell line was used to compare primary growth factor-dependent mast cells with a growth factor-independent cell line. Cell lysates were prepared from resting and $\mathrm{Fc} \varepsilon \mathrm{RI}$-activated BMMC grown for $10 \mathrm{~h}$ in the presence or absence of IL-3 and SCF (Figure 6a). The C57 mast cell line is growth factor independent, therefore these cells were deprived of serum instead of growth factors, and the cells were harvested and lysed $72 \mathrm{~h}$ after activation and/or serum deprivation (Figure $6 \mathrm{~b}$ ). All of the Bcl-2 family members analyzed were readily detectable in BMMC and C57 cells (Figure 6). These included the prosurvival proteins $\mathrm{Bcl}-\mathrm{X}_{\mathrm{L}}, \mathrm{Bcl}-2$ and $\mathrm{Bcl}-\mathrm{w}$, the proapoptotic multi $\mathrm{BH}$ domain protein Bak and the proapoptotic $\mathrm{BH}$-only proteins Bim, Bmf and Bad.

In agreement with our previous mRNA expression analysis, ${ }^{15}$ we could detect upregulation of $\mathrm{Bcl}-\mathrm{X}_{\mathrm{L}}$ protein levels upon IgE-receptor crosslinking, both in BMMC and in C57 cells (Figure 6). We also observed that withdrawal of IL-3 and
SCF caused a shift in migration of the $\mathrm{Bcl}-\mathrm{X}_{\mathrm{L}}$ and $\mathrm{Bcl}-2$ bands on the Western gel (Figure $6 \mathrm{a}$ ). The $\mathrm{Bcl}-\mathrm{X}_{\mathrm{L}}$ and $\mathrm{Bcl}-2$ proteins were found as distinct, slow-migrating bands in lysates from the growth factor-deprived cells, whereas lysates from cells grown in the presence of cytokines also contained fastermigrating proteins (Figure 6a). This shift in migration could be due to differences in phosphorylation status. Both $B c l-X_{L}$ and $\mathrm{Bcl}-2$ are known to be phosphorylated and dephosphorylated, and it has been reported that this can affect their function. ${ }^{20,21}$

It has been reported that Bim protein levels are increased upon growth factor withdrawal in several cell types. ${ }^{22,23}$ Surprisingly, we found that both $\mathrm{Bim}_{\mathrm{EL}}$ and $\mathrm{Bim}_{\mathrm{L}}$ were strongly increased following IgE-receptor activation (Figure 6). We also analyzed the expression of the Bcl-2 family members $\mathrm{Bim}, \mathrm{Bcl}-\mathrm{X}_{\mathrm{L}}$ and $\mathrm{Bcl}-2$ in BMMC produced in IL-3. A similar expression pattern could be observed in BMMC produced in IL-3 as for those produced in IL-3 plus SCF (Figure 6c). Bim and $\mathrm{Bcl}-\mathrm{X}_{\mathrm{L}}$ were induced after IgE-receptor activation, 


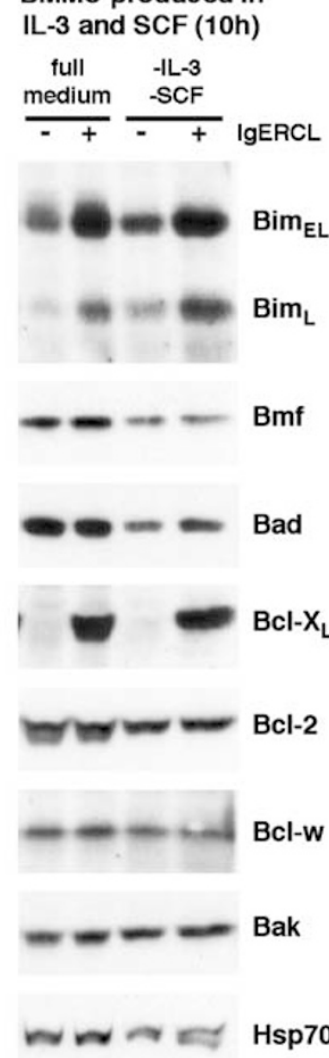

b

C57 mast cell line $(72 \mathrm{~h})$

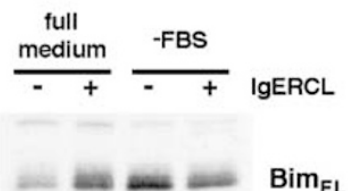

$-\ldots$ Bim $_{\mathrm{L}}$
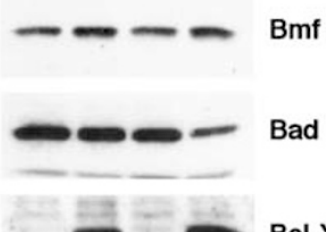

$B c l-X_{L}$

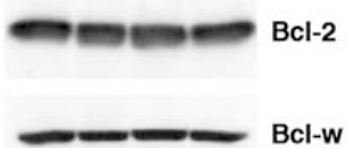

C
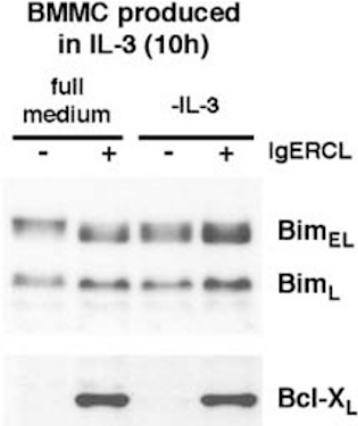

$\mathrm{Bcl}-2$

Actin d

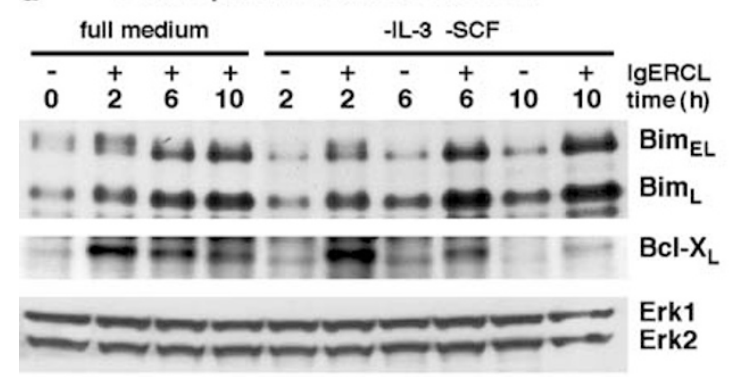

e BMMC produced in IL-3

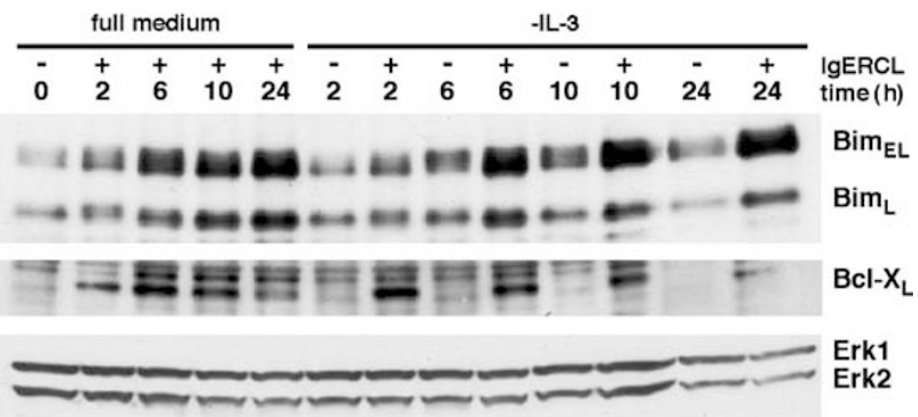

Figure 6 Crosslinking of $\mathrm{FC \varepsilon RI}$ by IgE increases the levels of Bim and Bcl-X proteins. (a) Wt BMMC produced in IL-3 and SCF were activated by IgE-receptor crosslinking, deprived of IL-3 and SCF, or subjected to both stimuli. After $10 \mathrm{~h}$, the levels of different Bcl-2 family members were analyzed by Western blotting using specific polyclonal or monoclonal antibodies. (b) C57, a cytokine-independent mast cell line, was stimulated by lgE-receptor crosslinking and/or deprived of FBS. After $72 \mathrm{~h}$, protein levels were analyzed as in (a). (c) Wt BMMC produced in IL-3 were activated by IgE-receptor crosslinking and/or deprived of IL-3. After 10 h, protein levels were analyzed as in (a). (d and e) BMMC produced in IL-3 plus SCF or in IL-3 alone were activated by IgE-receptor crosslinking and/or deprived of growth factors for varying periods of time. Protein levels were analyzed as in (a). (f) Cell lysates from BMMC produced in IL-3 plus SCF were treated with alkaline phosphatase, and then analyzed by Western blotting as in (a). The Probing with anti-Hsp70, anti-Actin, or anti-Erk Abs was used as control for the amount of proteins loaded. The results shown are representative of two independent experiments

whereas Bcl-2 levels were unaffected. This is the first observation that FcR activation can lead to upregulation of a proapoptotic BH3-only protein.

We further analyzed the kinetics of the IgE-receptor activation-induced upregulation of $\mathrm{Bim}$ and $\mathrm{Bcl}-\mathrm{X}_{\mathrm{L}}$. Both Bim and $\mathrm{Bcl}-\mathrm{X}_{\mathrm{L}}$ were upregulated $2 \mathrm{~h}$ after IgE-receptor crosslinking (Figure $6 \mathrm{~d}$ and $\mathrm{e}$ ). This was observed in the BMMC produced in IL-3 plus SCF as well as in the cells produced in IL-3 alone.
Growth factor deprivation changed both the level and the migration pattern of the Bim protein. In BMMC grown in the presence of IL-3 and SCF, Bim $\mathrm{EL}_{\mathrm{L}}$ consists of proteins migrating with slightly varying mobilities on SDS-PAGE giving rise to a blurry band (Figure 6a). However, following deprivation of IL-3 and SCF, only fast-migrating Bim $_{E L}$ was found. As for $\mathrm{Bcl}-\mathrm{X}_{\mathrm{L}}$ and $\mathrm{BCl}-2$, also the Bim protein has been reported to be a target for phosphorylation ${ }^{24}$ and this is thought to regulate its degradation through the proteasome 
pathway. ${ }^{25,26}$ In order to analyze whether the differences in migration mobility of $\mathrm{Bim}_{\mathrm{EL}}$ on the Western gel is due to differences in phosphorylation status of Bim $\mathrm{EL}_{\mathrm{L}}$, cell lysates from BMMC cultured in IL-3 plus SCF were treated with alkaline phosphatase before loading onto a Western gel. This treatment abolished the slower migrating portion of the Bim $\mathrm{EL}_{\mathrm{L}}$ band (Figure 6f), demonstrating that this upper band represents a phosphorylated form of Bim $\mathrm{BL}_{\mathrm{L}}$.

\section{Discussion}

Bim has been shown to be involved in the regulation of apoptosis in several cell types, including B lymphocytes, mature $\mathrm{T}$ lymphocytes, thymocytes, monocytes, granulocytes, osteoclasts and neurons. ${ }^{16,23,26-28}$ Our studies demonstrate for the first time that Bim is involved in the induction of mast cell death following growth factor withdrawal. Since we only observed a delay in the induction of death in bim-/- mast cells compared to wt cells, and not a total rescue, other factor(s) in addition to Bim most likely are involved in cytokine deprivation-induced mast cell death. It is possible that other $\mathrm{BH} 3-o n l y$ proteins expressed in mast cells play an important role in this cell death and this needs to be investigated further by using knockout mice lacking, for example, Bad, Blk, Puma or Bid. Puma is of particular interest since it has recently been shown that Puma plays a critical role in cytokine withdrawalinduced apoptosis of thymocytes and myeloid progenitors. ${ }^{29,30}$ The finding that overexpression of $\mathrm{Bcl}-2$ protected mast cells even more potently against cytokine withdrawalinduced apoptosis than did loss of Bim provides further evidence that other $\mathrm{Bcl}-2$ inhibitable death inducers besides Bim, most likely other BH3-only proteins, are involved in the mast cell death caused by growth factor deprivation.

In our experiments, we could observe some differences depending on how the BMMC were produced - in IL-3 alone or by costimulation of IL-3 plus SCF. For example, we found that $\mathrm{Bcl}-2$ protected more potently from growth factor deprivationinduced apoptosis in BMMC produced in IL-3 plus SCF compared to in BMMC produced in IL-3 alone. This may indicate that in mast cells $\mathrm{Bcl}-2$ can compensate more efficiently for SCF-receptor signaling than for IL-3 signaling. A possible explanation for this finding may be that $\mathrm{Bcl}-2$ noninhibitable death inducers contribute to the growth factor withdrawal-induced death of mast cells produced in only IL-3. Alternatively, $\mathrm{Bcl}-2$ may be more efficiently neutralized in mast cells produced in IL-3 alone compared to those produced in IL3 plus SCF.

We also observed that the BMMC produced in both IL-3 plus SCF proliferated much more rapidly than did the BMMC produced in IL-3 alone (data not shown). This is consistent with what has been observed by others. ${ }^{31}$ This may indicate that increased level of cytokine stimulation and increased cell cycling render mast cells (and perhaps also other cell types) more dependent on growth signals.

Another interesting finding was that mast cells produced in both IL-3 plus SCF undergo apoptosis much more rapidly upon growth factor withdrawal than does BMMC produced in IL-3 alone. A similar rapid decrease in mast cell viability upon SCF withdrawal from cells maintained in SCF has been reported earlier. ${ }^{19}$ Taken together, our results demonstrate that depending on whether mast cells have been produced in IL-3 alone or by the combined stimulation with IL-3 and SCF, the cells differ significantly in their response to growth factor deprivation.

It has been reported that crosslinking of the high-affinity $\lg \mathrm{E}$-receptor $\mathrm{F} c \varepsilon \mathrm{RI}$ elicits a prosurvival response in mast cells. ${ }^{15,32}$ We have previously shown that mRNA levels for the prosurvival genes $\mathrm{A} 1$ and $\mathrm{Bcl}-\mathrm{X}_{\mathrm{L}}$ are increased following $\mathrm{IgE}$ receptor crosslinking and that $A 1$ is critical for the activationinduced survival of mast cells. ${ }^{15}$ We investigated whether inhibition of Bim function is the most critical prosurvival stimulus elicited by IgE-receptor crosslinking. Our results do not support this hypothesis, but instead indicate that inhibition of Bim alone cannot be the sole prosurvival activity of $F_{c \varepsilon R}$ stimulation. Since $\mathrm{Fc}_{\varepsilon} \mathrm{RI}$ stimulation did not further increase the survival of cytokine-deprived mast cells overexpressing $\mathrm{Bcl}-2$, it is likely that this antiapoptotic signal prevents activation of certain $\mathrm{BH} 3-o n l y$ proteins, perhaps Puma or Bad, since they have been implicated in growth factor withdrawal-induced apoptosis. ${ }^{29,30,33}$

Not only were there differences in the mechanisms regulating apoptosis following growth factor withdrawal depending on the cytokines used for cell growth but we could also observe differences in the IgE-receptor activationinduced prosurvival stimuli. When BMMC produced in both IL-3 plus SCF were IgE-receptor activated followed by withdrawal of SCF alone, the mast cells did not survive better than did mast cells that had not been $F_{c \varepsilon} R I$ stimulated. In contrast, IgE-receptor stimulation elicited a prosurvival activity in mast cells deprived of both IL-3 and SCF. Moreover, in $\mathrm{Bcl}-2$-overexpressing mast cells produced in IL-3 plus SCF, there was no prosurvival response from IgE-receptor activation compared to resting mast cells, when depriving the cells of cytokines following the $\mathrm{F}_{\varepsilon} \mathrm{R}$ I stimulation. The protection of the cells may, in these experiments, already be maximal due to the overexpression of Bcl-2, which could explain why no further prosurvival effect is seen after $\mathrm{Fc}_{\varepsilon} \mathrm{Rl}$ activation.

In a previous study, we analyzed the mRNA levels of several Bcl-2 family members in resting and IgE-receptoractivated cells, and found that the prosurvival members A1 and $\mathrm{Bcl}-\mathrm{X}_{\mathrm{L}}$ were upregulated. ${ }^{15}$ However, at the protein level, it has not yet been thoroughly analyzed which Bcl-2 family members might be involved in the regulation of apoptosis following IgE-receptor crosslinking or growth factor withdrawal. It has previously been reported that SCF withdrawal leads to downregulation of the $\mathrm{Bcl}-2$ and $\mathrm{Bcl}-\mathrm{X}_{\mathrm{L}}$ protein levels in human mast cells. ${ }^{13}$ In some other cell types (e.g. Iymphoid or neuronal cells), the proapoptotic BH3-only protein Bim has been reported to be upregulated upon growth factor withdrawal, ${ }^{22,23,34}$ but the expression of Bim has not yet been studied in mast cells. In this study, we found that the prosurvival $\mathrm{Bcl}-\mathrm{X}_{\mathrm{L}}$ and, to our surprise, the proapoptotic Bim proteins were both strongly upregulated following IgEreceptor activation. This is the first time that it has been shown that FcR activation can result in upregulation of a proapoptotic $\mathrm{BH} 3-$ only protein. We have recently shown that activation of the T-cell receptor induces upregulation of Bim and that this is critical for the deletion of autoreactive thymocytes. $^{27}$ The signaling pathways responsible for 
FceRI-mediated upregulation of Bim needs to be further investigated. Mast cell activation through $\mathrm{Fc} \varepsilon \mathrm{RI}$ has been reported to stimulate the Akt signaling pathway. ${ }^{35}$ Activation of Akt has in several cell types been shown to result in phosphorylation, and hence inactivation, of forkhead transcription factors, such as FOXO3a. ${ }^{36}$ Since FOXO3a, when in an active state, is considered as an important transcription factor for Bim, ${ }^{22}$ the observed $\mathrm{FC}_{\varepsilon} \mathrm{RI}$-mediated upregulation of Bim was somewhat unexpected. Studies on other transcription factors besides forkhead transcription factors might shed light on signaling molecules that are responsible for the upregulation of Bim following IgE-receptor activation.

The finding that both prosurvival and proapoptotic members of the $\mathrm{Bcl}-2$ protein family are upregulated in response to $\lg \mathrm{E}$ receptor activation might explain why this type of activation in some experimental settings results in decreased cell death, while no prosurvival effect is seen in other conditions. Cell fate is likely to be determined by the balance between the prosurvival and the proapoptotic molecules.

An interesting observation was that deprivation of IL-3 and SCF from mast cells can alter the phosphorylation state of several Bcl-2 family members, including Bim, Bcl-2 and Bcl$X_{L}$. Bim becomes dephosphorylated following withdrawal of IL-3 and SCF, while Bcl-2 and $\mathrm{Bcl}-\mathrm{X}_{\mathrm{L}}$ appear to be phosphorylated. Several previous studies have demonstrated that the phosphorylation status can affect the function of these proteins. $^{20,21,25}$

Although Bim is clearly an initiator of cytokine deprivationinduced mast cell death, our results indicate that other proteins are also involved in this process. Since overexpression of $\mathrm{Bcl}-2$ protected mast cells against cytokine withdrawal more potently than loss of $\mathrm{Bim}$, other $\mathrm{Bcl}-2$ inhibitable proteins, quite likely other BH3-only proteins, are probably activated by growth factor deprivation. Our expression analysis shows that neither Bmf nor Bad protein levels are increased upon IL-3/SCF deprivation, but these proteins might still be involved in this process if their proapoptotic activity is activated by a post-translational mechanism. Moreover, there exist several other BH3-only proteins that remain to be studied for their role in regulating mast cell apoptosis.

Collectively, our results show that Bim, together with other Bcl-2 inhibitable proteins, is involved in the regulation of apoptosis and survival of mast cells. In Figure 7a, a model is presented on how cytokine withdrawal could lead to mast cell apoptosis by activating Bim and other BH3-only proteins, thereby inhibiting the prosurvival effect of $\mathrm{Bcl}-2$ and other prosurvival homologs. We have also found that IgE-receptor crosslinking upregulates the protein levels of both prosurvival and proapoptotic Bcl-2 family members, namely, Bcl- $X_{L}$ and Bim. Considering these results and previously published data regarding the involvement of $\mathrm{A} 1$ in IgE-receptor activationinduced mast cell survival, ${ }^{15}$ we present a model for how the fate of mast cells following IgE-receptor crosslinking could be fine-tuned by prosurvival and proapoptotic Bcl-2 family members (Figure $7 \mathrm{~b}$ ). The balance between proapoptotic and prosurvival members of the $\mathrm{Bcl}-2$ protein family depends on the amounts of different family members present in a cell. Circumstances that could affect the prosurvival/proapoptotic balance include whether the proteins are in active or inactive
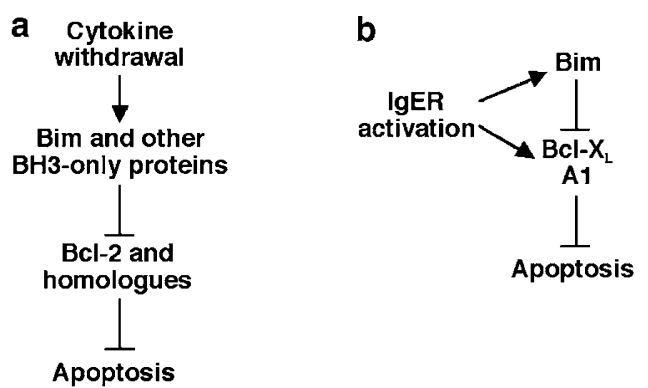

Figure 7 Two possible models for the role of Bim in the regulation of mast cell survival. (a) A mechanism by which cytokine withdrawal induces mast cells to undergo apoptosis could be that Bim and activation of other BH3-only proteins hinder prosurvival $\mathrm{Bcl}-2$ homologues from performing their antiapoptotic function. (b) Crosslinking of the $\mathrm{Fc} \varepsilon \mathrm{RI}$ by $\mathrm{lgE}$ leads to upregulation of both prosurvival and proapoptotic members of the Bcl-2 family. The balance between prosurvival and proapoptotic proteins following IgE-receptor activation of mast cells might determine if the net result of the receptor activation is increased survival or apoptosis

forms, the subcellular localization of these proteins and the mode of interaction between the different family members. ${ }^{37}$

\section{Materials and Methods}

\section{Mice}

The mice used were Bim-deficient (266/266del) mice backcrossed for more than 12 generations onto a C57BL/6J genetic background, ${ }^{16}$ vav$b c l-2-69$ transgenic mice, expressing human $\mathrm{Bcl}-2$ under control of the vav promoter in all hemopoietic cells, on an inbred C57BL/6J genetic background $^{17}$ and wt C57BL/6J mice (from the Walter and Eliza Hall Institute mouse breeding facility, Kew, Australia). All experiments with animals were performed according to the guidelines of the Royal Melbourne Hospital Research Foundation Animal Ethics Committee.

\section{Mast cell cultures}

BMMC were obtained by culturing mouse bone marrow cells in RPMI medium (Gibco) supplemented with 10\% heat-inactivated fetal bovine serum (FBS) (TRACE Scientific), $50 \mu \mathrm{M}$ 2-ME, $50 \mu \mathrm{g} / \mathrm{ml}$ penicillin, $25 \mu \mathrm{g} /$ $\mathrm{ml}$ streptomycin and $1000 \mathrm{U} / \mathrm{ml}$ of IL-3 (produced by X63/0 cells transfected with a mouse IL-3 expression construct). Alternatively, BMMC were produced in medium supplemented with $1000 \mathrm{U} / \mathrm{ml} \mathrm{IL-3} \mathrm{and} 25 \mathrm{ng} / \mathrm{ml}$ SCF (rmSCF, produced in Pichia pastoris and purified from culture supernatants by reverse phase chromatography). In one experiment for analysis of protein levels, BMMC were obtained by culturing in RPMI medium (Sigma) supplemented with 10\% heat-inactivated FBS (Gibco), $10 \mathrm{mM}$ HEPES buffer, $1 \times$ MEM nonessential amino-acid solution, $1 \mathrm{mM}$ sodium pyruvate, $2 \mathrm{mM}$ L-glutamine (all from Sigma), $50 \mu \mathrm{M}$ 2-ME, $100 \mathrm{IU} /$ $\mathrm{ml}$ penicillin G, $50 \mu \mathrm{g} / \mathrm{ml}$ streptomycin and $5 \mathrm{ng} / \mathrm{ml} \mathrm{IL-3} \mathrm{(rmlL-3,}$ PeproTech). All bone marrow-derived mast cells were cultured for a minimum of 3 weeks before they were used, and no experiments were performed on cells older than 9 weeks. The maturity and purity of the cells were examined by toluidine blue staining. Expression of Kit and Fc\&RI was analyzed by flow cytometric analysis using FITC-anti-mouse CD117 (c-Kit) (2B8), FITC-conjugated rat $\lg _{2 b}$ isotype control (both from Pharmingen), FITC-conjugated anti-mouse Fc $\varepsilon \mathrm{RI}-\alpha$ (MAR-1) and FITC-conjugated Armenian Hamster lgG isotype control (both from eBioscience).

The mast cell line $\mathrm{C}^{3} 7^{38}$ (a gift from Dr. SJ Galli, Stanford University, Stanford, CA, USA) was cultured in RPMI medium (Gibco) supplemented 
with $10 \%$ heat-inactivated FBS, $50 \mu \mathrm{M}$ 2-ME, $50 \mu \mathrm{g} / \mathrm{ml}$ penicillin and $25 \mu \mathrm{g} / \mathrm{ml}$ streptomycin.

\section{Mast cell activation}

For activation through crosslinking of the IgE-receptor, mast cells were sensitized for $90 \mathrm{~min}$ at $37^{\circ} \mathrm{C}$ with a monoclonal mouse anti-TNP IgEantibody (IgEl-b4, ATCC), used as a 15\% v/v hybridoma supernatant (corresponding to $1.5 \mu \mathrm{g} / \mathrm{ml} \mathrm{lgE}$ ). After two washings in PBS, the cells were resuspended in medium and activated by addition of $100 \mathrm{ng} / \mathrm{ml}$ TNPBSA (coupling ratio: 9/1) (Biosearch Technologies). To the control cells neither IgE nor TNP were added, but the cells were subjected to the washing and incubation steps.

\section{Cell death assay}

To monitor cell death, cells were stained with propidium iodide $(2 \mu \mathrm{g} / \mathrm{ml})$ and analyzed in a FACScan (Becton Dickinson). Values presented are the means \pm S.D. $(n=4-6)$. For statistical analysis, we used an analysis of variance (ANOVA) followed by multiple comparison by Fisher's method. Differences were considered significant at $P<0.05$.

\section{Western blotting}

Cells were lysed in buffer containing $0.05 \mathrm{M}$ Pipes- $\mathrm{NaOH}, 0.05 \mathrm{M}$ Hepes, $\mathrm{pH} 7.0,2 \mathrm{mM} \mathrm{MgCl}_{2}, 1 \mathrm{mM}$ EDTA, $1 \%$ Triton-X 100 and Complete Protease Inhibitor Cocktail tablets (Roche). The nuclei were pelleted, and the soluble fraction was used for analysis. Proteins were size-separated under reducing conditions by SDS-PAGE (NOVEX) and transferred onto nitrocellulose membranes (Amersham Biosciences). The membranes were probed with either of the following antibodies: rabbit polyclonal anti-Bim, anti-Bad, anti-Bcl-w (all from Stressgen Biotechnologies, the Bim antibody detects both $\operatorname{Bim}_{\mathrm{EL}}$ and $\mathrm{Bim}_{\mathrm{L}}$ ), anti-Bim (Affinity BioReagents, detecting both $\operatorname{Bim}_{\mathrm{EL}}$ and $\mathrm{Bim}_{\mathrm{L}}$ ), anti-Bmf, ${ }^{39}$ anti-Bak (Sigma), anti-Bcl-2, anti-Erk, (both from Santa Cruz Biotechnology), mouse monoclonal anti-Bcl-X (clone 7B2.5, a gift from Professor C Thompson, Abramson Institute, Pennsylvania, PA, USA), anti-Hsp70 (a gift from Dr. R Anderson, Peter MacCallum Cancer Institute, Melbourne), rat monoclonal anti-Bcl-w (clone $16 \mathrm{H} 12^{40}$ ), hamster monoclonal anti-mouse Bcl-2 (clone 3F11, a gift from Professor S Korsmeyer, Dana-Farber Cancer Institute, Boston, MA, USA), HRP-conjugated goat polyclonal anti-Actin (Santa Cruz Biotechnology). The HRP-conjugated secondary antibodies used were either sheep antirabbit Ig, sheep anti-mouse Ig (both Silenus Labs), goat anti-rabbit lg (Cell Signaling Technology), sheep anti-mouse Ig (Amersham Life Science), goat anti-rat Ig or goat anti-hamster Ig (both Southern Biotechnology Associates). Enhanced chemiluminescence system was used for detection. Each experiment was performed twice independently. For the experiments performed on BMMC, the cells were derived from separate mice.

\section{Treatment with alkaline phosphatase}

Cell lysates were divided into two fractions. One fraction was incubated in dephosphorylation buffer and $200 \mathrm{U} / \mathrm{ml}$ of alkaline phosphatase (both from Roche) at $40^{\circ} \mathrm{C}$ for $1 \mathrm{~h}$. The other fraction (control) was treated in the same way, but without the addition of alkaline phosphatase. After treatment, the lysates were analyzed by Western blotting.

\section{Acknowledgements}

We thank Drs. Philippe Bouillet, Alan Harris and Professors Jerry Adams, and Suzanne Cory for providing the bim-I- and vav-bcl-2 transgenic mice, Phillip Morgan for help in the production of SCF, Professors Craig Thompson, Stan Korsmeyer and Dr. Robin Anderson for antibodies, Professor Stephen Galli for C57 cells, and Professor Birgitta Heyman and Mrs. Imma Brogren for help with analyzing the concentration of $\mathrm{IgE}$. This work was supported by grants from The Swedish Cancer Society, The Swedish Research Council, Goran Gustafsson's Foundation, King Gustav V's 80 years Foundation, Ollie and Elof Ericsson's Foundation, Anna Cederberg's Foundation, Knut and Alice Wallenberg's Foundation (all from Sweden), the NHMRC (Canberra), the Leukemia and Lymphoma Society of America and the Cancer Research Institute (New York).

\section{References}

1. Wedemeyer J, Tsai M and Galli SJ (2000) Roles of mast cells and basophils in innate and acquired immunity. Curr. Opin. Immunol. 12: 624-631

2. Benoist $C$ and Mathis $D(2002)$ Mast cells in autoimmune disease. Nature 420: 875-878

3. Viegas M, Gomez E, Brooks J and Davies RJ (1987) Changes in nasal mast cell numbers in and out of the pollen season. Int. Arch. Allergy. Appl. Immunol. 82: $275-276$

4. Gibson PG, Allen CJ, Yang JP, Wong BJ, Dolovich J, Denburg $\mathrm{J}$ and Hargreave FE (1993) Intraepithelial mast cells in allergic and nonallergic asthma. Assessment using bronchial brushings. Am. Rev. Resp. Dis. 148: 80-86

5. Godfrey HP, Ilardi C, Engber W and Graziano FM (1984) Quantitation of human synovial mast cells in rheumatoid arthritis and other rheumatic diseases. Arthritis Rheum. 27: 852-856

6. Strasser A, Harris AW, Huang DC, Krammer PH and Cory S (1995) Bcl-2 and Fas/APO-1 regulate distinct pathways to lymphocyte apoptosis. EMBO J. 14: 6136-6147

7. Marsden VS and Strasser A (2003) Control of apoptosis in the immune system: Bcl-2, BH3-only proteins and more. Annu. Rev. Immunol. 21: 71-105

8. Huang DC and Strasser A (2000) BH3-only proteins - essential initiators of apoptotic cell death. Cell 103: 839-842

9. Zong WX, Lindsten T, Ross AJ, MacGregor GR and Thompson CB (2001) $\mathrm{BH} 3-$ only proteins that bind pro-survival $\mathrm{Bcl}-2$ family members fail to induce apoptosis in the absence of Bax and Bak. Genes Dev. 15: 1481-1486

10. Cheng EH, Wei MC, Weiler S, Flavell RA, Mak TW, Lindsten T and Korsmeyer SJ (2001) BCL-2, BCL-X(L) sequester BH3 domain-only molecules preventing BAX- and BAK-mediated mitochondrial apoptosis. Mol. Cell 8: 705-711

11. Cervero C, Escribano L, San Miguel JF, Diaz-Agustin B, Bravo P, Villarrubia J, Garcia-Sanz R, Velasco JL, Herrera P, Vargas M, Gonzalez M, Navarro JL and Orfao A (1999) Expression of Bcl-2 by human bone marrow mast cells and its overexpression in mast cell leukemia. Am. J. Hematol. 60: 191-195

12. Yeatman II CF, Jacobs-Helber SM, Mirmonsef $P$, Gillespie $S R$, Bouton LA, Collins HA, Sawyer ST, Shelburne CP and Ryan JJ (2000) Combined stimulation with the Thelper cell type 2 cytokines interleukin (IL)-4 and IL-10 induces mouse mast cell apoptosis. J. Exp. Med. 192: 1093-1103

13. Mekori YA, Gilfillan AM, Akin C, Hartmann K and Metcalfe DD (2001) Human mast cell apoptosis is regulated through $\mathrm{BCl}-2$ and $\mathrm{Bcl}-\mathrm{XL}$. J. Clin. Immunol. 21: $171-174$

14. Maurer M, Tsai M, Metz M, Fish S, Korsmeyer SJ and Galli SJ (2000) A role for Bax in the regulation of apoptosis in mouse mast cells. J. Invest. Dermatol. 114: 1205-1206

15. Xiang Z, Ahmed AA, Moller C, Nakayama K, Hatakeyama S and Nilsson G (2001) Essential role of the prosurvival bcl-2 homologue A1 in mast cell survival after allergic activation. J. Exp. Med. 194: 1561-1569

16. Bouillet $P$, Metcalf $D$, Huang DC, Tarlinton DM, Kay TW, Kontgen F, Adams JM and Strasser A (1999) Proapoptotic Bcl-2 relative Bim required for certain apoptotic responses, leukocyte homeostasis, and to preclude autoimmunity. Science 286: 1735-1738

17. Ogilvy S, Metcalf D, Print CG, Bath ML, Harris AW and Adams JM (1999) Constitutive Bcl-2 expression throughout the hematopoietic compartment affects multiple lineages and enhances progenitor cell survival. Proc. Natl. Acad. Sci. U.S.A. 96: 14943-14948 
18. Mekori YA, Oh CK and Metcalfe DD (1993) IL-3-dependent murine mast cells undergo apoptosis on removal of IL-3. Prevention of apoptosis by c-kit ligand. J. Immunol. 151: 3775-3784

19. lemura A, Tsai M, Ando A, Wershil BK and Galli SJ (1994) The c-kit ligand, stem cell factor, promotes mast cell survival by suppressing apoptosis. Am. J. Pathol. 144: 321-328

20. Poruchynsky MS, Wang EE, Rudin CM, Blagosklonny MV and Fojo T (1998) $\mathrm{BCl}-\mathrm{xL}$ is phosphorylated in malignant cells following microtubule disruption. Cancer Res. 58: 3331-3338

21. Haldar S, Jena N and Croce CM (1994) Antiapoptosis potential of bcl-2 oncogene by dephosphorylation. Biochem. Cell Biol. 72: 455-462

22. Dijkers PF, Medemadagger RH, Lammers JW, Koenderman $L$ and Coffer PJ (2000) Expression of the pro-apoptotic Bcl-2 family member Bim is regulated by the forkhead transcription factor FKHR-L1. Curr. Biol. 10: 1201-1204

23. Putcha GV, Moulder KL, Golden JP, Bouillet P, Adams JA, Strasser A and Johnson EM (2001) Induction of BIM, a proapoptotic BH3-only BCL-2 family member, is critical for neuronal apoptosis. Neuron 29: 615-628

24. Shinjyo T, Kuribara R, Inukai T, Hosoi H, Kinoshita T, Miyajima A, Houghton PJ, Look AT, Ozawa K and Inaba T (2001) Downregulation of Bim, a proapoptotic relative of $\mathrm{Bcl}-2$, is a pivotal step in cytokine-initiated survival signaling in murine hematopoietic progenitors. Mol. Cell. Biol. 21: 854-864

25. Ley R, Balmanno K, Hadfield K, Weston C and Cook SJ (2003) Activation of the ERK1/2 signaling pathway promotes phosphorylation and proteasomedependent degradation of the $\mathrm{BH} 3-$ only protein, Bim. J. Biol. Chem. 278 : 18811-18816

26. Akiyama T, Bouillet $P$, Miyazaki T, Kadono Y, Chikuda H, Chung UI, Fukuda A, Hikita A, Seto H, Okada T, Inaba T, Sanjay A, Baron R, Kawaguchi H, Oda H, Nakamura K, Strasser A and Tanaka S (2003) Regulation of osteoclast apoptosis by ubiquitylation of proapoptotic $\mathrm{BH} 3-$ only $\mathrm{Bcl}-2$ family member $\mathrm{Bim}$. EMBO J. 22: 6653-6664

27. Bouillet P, Purton JF, Godfrey DI, Zhang LC, Coultas L, Puthalakath H, Pellegrini M, Cory S, Adams JM and Strasser A (2002) BH3-only Bcl-2 family member Bim is required for apoptosis of autoreactive thymocytes. Nature 415: 922-926

28. Villunger $A$, Scott $C$, Bouillet $P$ and Strasser $A$ (2003) Essential role for the $\mathrm{BH} 3-$ only protein Bim but redundant roles for Bax, Bcl-2, and Bcl-w in the control of granulocyte survival. Blood 101: 2393-2400

29. Villunger A, Michalak EM, Coultas L, Mullauer F, Bock G, Ausserlechner MJ, Adams JM and Strasser A (2003) p53- and drug-induced apoptotic responses mediated by $\mathrm{BH} 3-$ only proteins puma and noxa. Science 302 : $1036-1038$

30. Jeffers JR, Parganas E, Lee Y, Yang C, Wang J, Brennan J, MacLean KH, Han J, Chittenden T, Ihle JN, McKinnon PJ, Cleveland JL and Zambetti GP (2003) Puma is an essential mediator of p53-dependent and -independent apoptotic pathways. Cancer Cell 4: 321-328

31. Itakura A, Miura Y, Hikasa Y, Kiso Y and Matsuda H (2001) Interleukin-3 and stem cell factor modulate cell cycle regulatory factors in mast cells: negative regulation of p27Kip1 in proliferation of mast cells induced by interleukin-3 but not stem cell factor. Exp. Hematol. 29: 803-811

32. Yoshikawa H, Nakajima $Y$ and Tasaka K (1999) Glucocorticoid suppresses autocrine survival of mast cells by inhibiting IL-4 production and ICAM-1 expression. J. Immunol. 162: 6162-6170

33. Ranger AM, Zha J, Harada H, Datta SR, Danial NN, Gilmore AP, Kutok JL, Le Beau MM, Greenberg ME and Korsmeyer SJ (2003) Bad-deficient mice develop diffuse large B cell lymphoma. Proc. Natl. Acad. Sci. U.S.A. 100: 93249329

34. Bouillet $P$ and Strasser A (2002) BH3-only proteins - evolutionarily conserved proapoptotic $\mathrm{Bcl}-2$ family members essential for initiating programmed cell death. J. Cell. Sci. 115: 1567-1574

35. Kitaura J, Asai K, Maeda-Yamamoto M, Kawakami Y, Kikkawa U and Kawakami T (2000) Akt-dependent cytokine production in mast cells. J. Exp. Med. 192: 729-740

36. Brunet A, Bonni A, Zigmond MJ, Lin MZ, Juo P, Hu LS, Anderson MJ, Arden KC, Blenis J and Greenberg ME (1999) Akt promotes cell survival by phosphorylating and inhibiting a Forkhead transcription factor. Cell 96: 857868

37. Adams JM (2003) Ways of dying: multiple pathways to apoptosis. Genes Dev. 17: $2481-2495$

38. Young JD, Liu CC, Butler G, Cohn ZA and Galli SJ (1987) Identification, purification, and characterization of a mast cell-associated cytolytic factor related to tumor necrosis factor. Proc. Natl. Acad. Sci. U.S.A. 84: 9175-9179

39. Puthalakath H, Villunger A, O'Reilly LA, Beaumont JG, Coultas L, Cheney RE, Huang DC and Strasser A (2001) Bmf: a proapoptotic BH3-only protein regulated by interaction with the myosin $\mathrm{V}$ actin motor complex, activated by anoikis. Science 293: 1829-1832

40. O'Reilly LA, Print C, Hausmann G, Moriishi K, Cory S, Huang DC and Strasser A (2001) Tissue expression and subcellular localization of the pro-survival molecule Bcl-w. Cell Death Differ. 8: 486-494 